\title{
Effect of Cross-cutting and Temperature on Shoot and Root Growth of Onion Bulb
}

\author{
Kil Sun Yoo ${ }^{1}$ and Leonard M. Pike ${ }^{2}$ \\ Vegetable Improvement Center, Department of Horticultural Sciences, Texas \\ A\&M University, College Station, TX 77843
}

Additional index words. Allium cepa, dormancy, tissue removal

Several attempts have been made to stimulate sprouting of dormant onion bulbs. Lumis and Evans (1928) promoted sprouting by crosscutting, splitting, and injecting water into onion (Allium cepa L.) bulbs. However, in another study, bulbs with $\approx 50 \%$ of the upper portion removed by cross-cutting, planted in August in Texas and New Mexico for seed production, did not sprout (unpublished data). This observation implies that temperature may play an important role in shoot growth of onion bulbs. Therefore, we determined the effects of removing bulb tissues by crosscutting (i.e., removal of a portion of the bulb) and growing bulbs in various temperatures on shoot and root growth in dormant onion bulbs.

'Texas Grano 1015Y' onion bulbs (5.0 to $8.8 \mathrm{~cm}$ in diameter) were harvested on $25 \mathrm{Apr}$. and held at $24 \mathrm{C}$ for 2 weeks for curing. They were cross-cut at half $(50 \%$ removal) or onequarter (75\% removal) of their height (measured from the root plate). The control remained whole. The bulbs were planted in trays $(38 \times 58 \times 14 \mathrm{~cm})$ filled with wet vermiculite and covered by transparent plastic film to maintain humidity. Each removal treatment consisted of three trays with 20 bulbs each.

Three trays, one from each treatment, were placed in growth chambers set at 15,25 , or 30C with 24-h fluorescent light (15 $\mu \mathrm{mol} \cdot \mathrm{m}^{-2} \cdot \mathrm{s}^{-1}$ ) for 4 weeks. Leaf length, including the internal portion in the bulbs, and root fresh weight were measured.

Shoot growth was promoted by removing portions of bulbs at 15 and $25 \mathrm{C} ; 75 \%$ removal resulted in the largest shoots (Fig. 1, top). However, shoot growth was negligible at 30C regardless of the removal percentage. Shoot growth generally was less with higher temperatures. There was a highly significant removal percentage $\times$ temperature interaction. This interaction seemed to reflect the nonlinear response of shoot growth to temperature.

Received for publication 10 Aug. 1994. Accepted for publication 9 Nov. 1994. The cost of publishing this paper was defrayed in part by the payment of page charges. Under postal regulations, this paper therefore must be hereby marked advertisement solely to indicate this fact.

${ }^{1}$ Research Assistant Professor.

${ }^{2}$ Professor.
Root growth was most active at $15 \mathrm{C}$, followed by $25 \mathrm{C}$, and was almost absent at $30 \mathrm{C}$ (Fig. 1, bottom). Unlike shoot growth, root growth was most abundant in the control $(0 \%$ removal) and was inversely associated with removal percentage at $15 \mathrm{C}$. Removal percentage had no effect on root growth at 25 and 30C. There also was a highly significant removal treatment $\times$ temperature treatment interaction. Because the roots grew soon after harvest when temperature was appropriate, dormancy must have been absent. The reason for the substantial root growth in the control bulbs at 15 and $25 \mathrm{C}$ was not clear, but it may be associated with large amounts of water and nutrient materials from the storage tissue.

Our results at 15 and $25 \mathrm{C}$ were similar to those of Lumis and Evans (1928), who reported that increasing removal of outer scales promoted greater shoot growth at an unspecified temperature. In our study, however, we found that shoot and root growth were controlled by removal percentage at $\leq 25 \mathrm{C}$ but were inhibited strongly at $30 \mathrm{C}$ regardless of removal percentage. This result indicates that shoot and root growth were controlled primarily by temperature and secondarily by removal of bulb tissue.

Neither free access of oxygen to the growing point by removal of bulb tissue (Lumis and Evans, 1928) nor changes in the balance of growth substances (Mahotiere et al., 1976) could explain this result completely. We propose that onion bulbs have a dormancy mechanism that is activated at $\approx 30 \mathrm{C}$.

Onion breeders or seed producers wanting to hasten bulb growth in a greenhouse or during high-temperature seasons must remove $\approx 50 \%$ to $75 \%$ of the upper portion of the bulbs and plant them where temperature can be maintained between 15 to $25 \mathrm{C}$.

\section{Literature Cited}

Lumis, W.E. and M.M. Evans. 1928. Experiments in breaking the rest period of corms and bulbs. Proc. Amer. Soc. Hort. Sci. 25:73-79.

Mahotiere, S., R.C. Herner, and F.G. Dennis. 1976. Effect of applied growth substances on growth of shoot apices excised from onions in rest. J. Amer. Soc. Hort. Sci. 101:211-213.

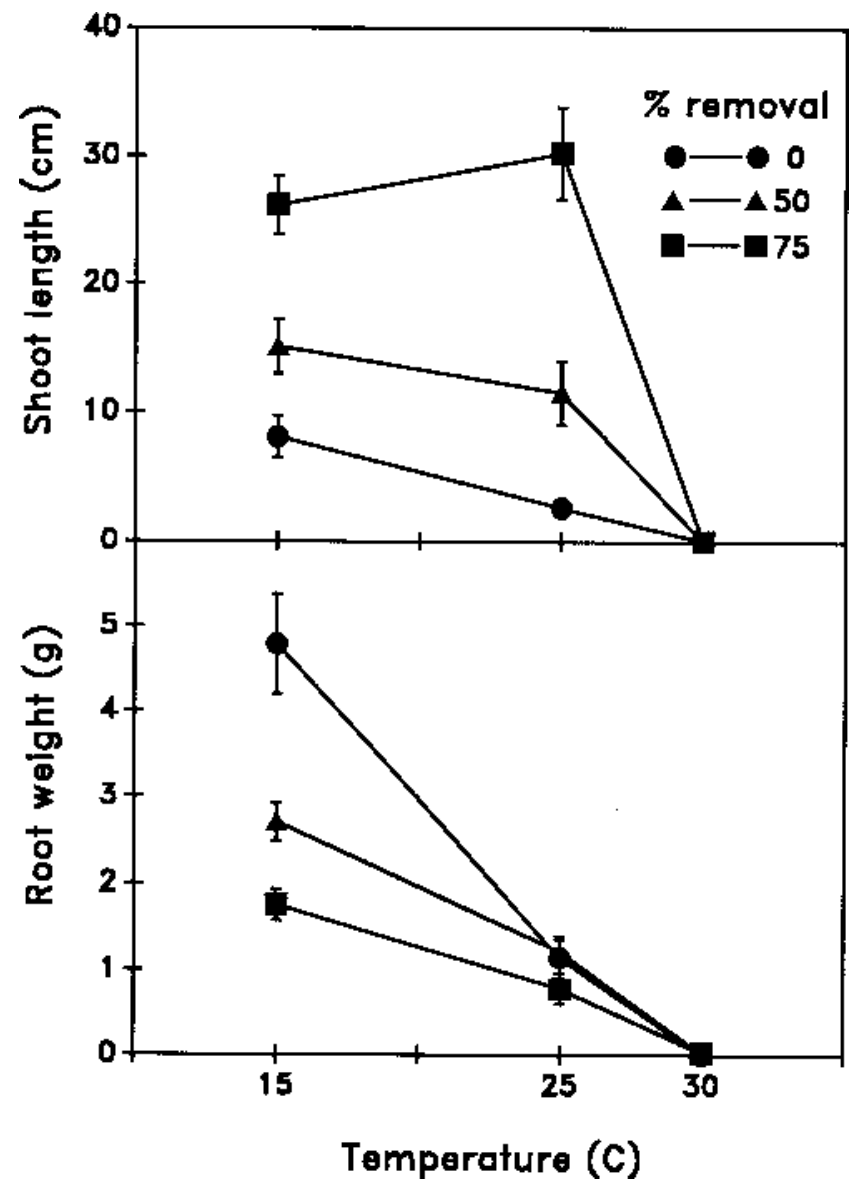

Fig. 1. Effect of removing onion bulb tissues by cross-cutting and growing bulbs at various temperatures on shoot and root growth after 4 weeks. Each point is mean of 20 bulbs; vertical bars indicate SE. 